\title{
Political Science Research and Methods
}

THE JOURNAL OF THE EUROPEAN POLITICAL SCIENCE ASSOCIATION

Political Science Research and Methods (PSRM) is a general political science journal dedicated to publishing original scholarly work of the highest quality from all subfields of political science.

PSRM seeks research that applies rigorous methods to empirical or theoretical problems and promotes a rigorous scientific approach to the study of politics. Work at the intersection of political science and related disciplines such as economics and sociology is also welcomed.

Follow: twitter.com/PSRMjournal

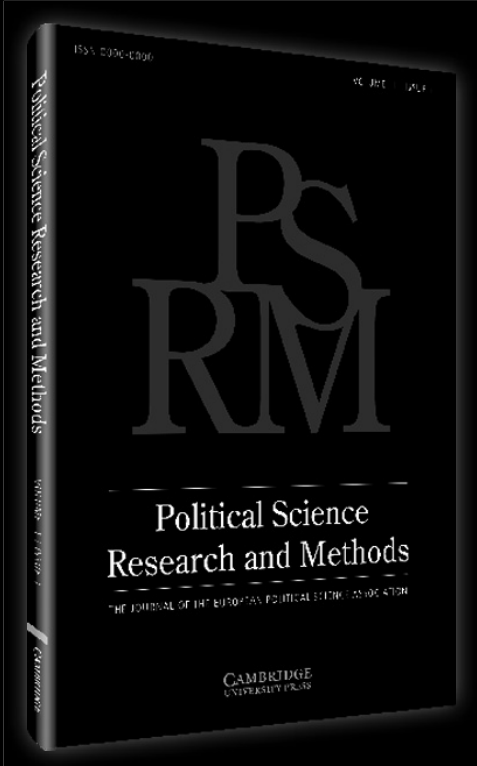

Sign up for content alerts, find out how to submit your paper, recommend PSRM to your librarian and more at the journal homepage here: journals.cambridge.org/psrm 


\section{SUBSCRIPTION RATES 2015}

This journal is published 4 times per year in January, April, July and October. The institutional rates (excluding VAT) are:

$\begin{array}{llll} & \text { Print and Online } & \text { Electronic Only } & \text { Print Only } \\ \text { USD } & 391 & 341 & 361 \\ \text { GBP } & 225 & 188 & 202 \\ \text { EUR } & 284 & 242 & 256\end{array}$

Individual subscribers should contact the relevant Cambridge office for individual subscription rates. EU subscribers (outside the UK) who are not registered for VAT should add VAT at their country's rate. VAT registered subscribers should provide their VAT registration number. Prices include delivery by air when appropriate. Japanese prices for institutions are available from Kinokuniya Company Ltd, P.O. Box 55, Chitose, Tokyo 156, Japan.

Orders and subscription enquiries should be addressed to: Cambridge University Press, Journals Fulfillment Department, UPH, Shaftesbury Road, Cambridge CB2 8BS, UK.

Orders from N America should be addressed to:

Cambridge University Press, Journals Fulfillment Department, 100 Brook Hill Drive, West Nyack, NY 10994-2133, USA

Government \& Opposition and all other Cambridge Journals can be found at http://journals.cambridge.org/

\section{Rights and Permissions}

This journal is registered with the Copyright Clearance Center, 222 Rosewood Drive, Danvers, MA 01923, USA. Organizations in the USA who are also registered with the C.C.C. may, therefore copy material (beyond the limits permitted by, sections 107 and 108 of U.S. Copyright law) subject to payment to the C.C.C. of the appropriate fee per copy. This consent does not extend to multiple copying for promotional or commercial purposes. For all other use, permission should be sought from Cambridge or the American Branch of Cambridge University Press.

(C) Government and Opposition Ltd 2015

\section{Disclaimer}

The Publisher, Government and Opposition Ltd and Editors cannot be held responsible for errors or any consequences arising from the use of information contained in this journal; the views and opinions expressed do not necessarily reflect those of the Publisher, Government and Opposition Ltd and Editors, neither does the publication of advertisements constitute any endorsement by the Publisher, Government and Opposition Ltd and Editors of the products advertised. 


\section{Government Opposition}

\section{ARTICLES}

Which Map? Which Government? Malapportionment and Gerrymandering, UK-Style (The Government and Opposition/Leonard Schapiro Memorial Lecture, 2014)

Ron Johnston

Transitional Justice and Changing Memories of the Past in Central Europe

Roman David

Beyond the Usual Suspects: Non-Left, Male and Non-Feminist MPs

and the Substantive Representation of Women

Karen Celis and Silvia Erzeel

Party Competition in the 2013 Italian Elections: Evidence

from an Expert Survey

Aldo Di Virgilio, Daniela Giannetti, Andrea Pedrazzani and Luca Pinto

65

Re-election: Different Skills for Different Roles

Osnat Akirav

90

Political Change and Civil Society Coalitions in Singapore

Stephan Ortmann

\section{REVIEW ARTICLE}

'East is East, and West is West'? Reimagining Asian Exceptionalism and the Study of Democratization

O. Fiona Yap 